\title{
Pituitary function studies in a case of mild Hunter's syndrome (MPS IIB)
}

\author{
JOHN NELSON* AND DENNIS CARSON† \\ Departments of Medical Genetics* and Child Health†, The Queen's University of Belfast. Belfast.
}

SUMMARY Pituitary function studies were performed in a patient with mild Hunter's syndrome (mucopolysaccharidosis type IIB, MPS IIB) in order to exclude growth hormone deficiency as a possible contributing cause of his short stature. The results indicated that anterior pituitary function and, in particular, growth hormone secretion was normal. The most likely explanation for the short stature is an osseous growth plate disturbance with infiltration of the epiphyses by mucopolysaccharides.

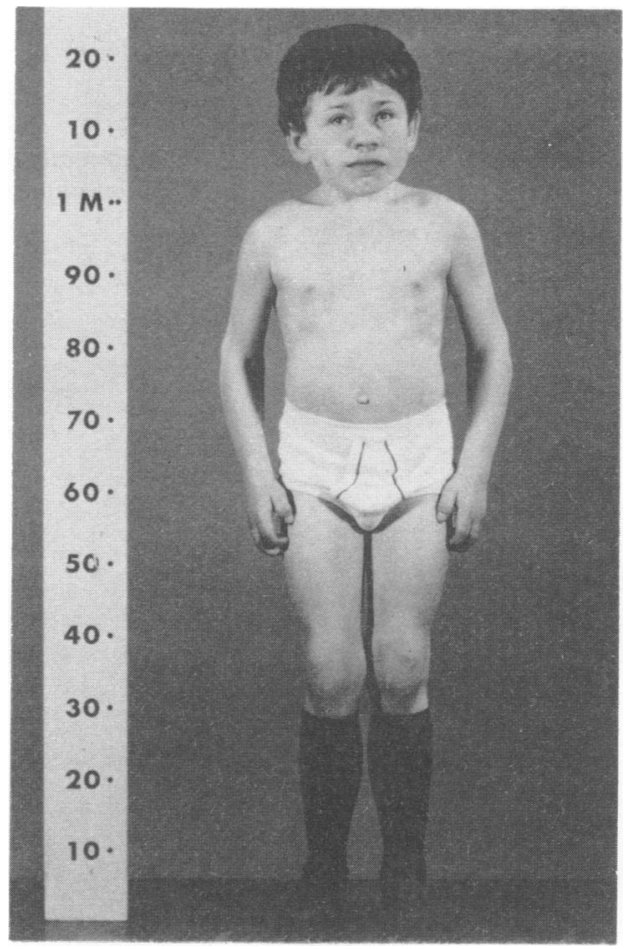

FIGURE Note the slightly coarse facial features, limitation of elbow extension, slight genu valgum, and typical clawing of the hands.

Received for publication 5 April 1989 Accepted for publication 8 May 1989.

\section{Case report}

The patient was aged 13.7 years and was one of a sibship of eight. He had one normal brother and six normal sisters. There was no other family history of Hunter's syndrome. Diagnosis was confirmed by two dimensional electrophoresis of urinary glycosaminoglycans and by iduronate sulphatase assay on serum. He was attending the partial hearing unit of a normal secondary school and was coping well. However, he was becoming very conscious of his short stature and since it had been suggested by a number of authors ${ }^{1-4}$ that pituitary function might be compromised in Hunter's syndrome it was decided to investigate his growth hormone status.

Clinical examination showed the slightly coarse facial features of Hunter's syndrome. He had typical clawing of the hands, limitation of elbow extension and wrist flexion, hepatomegaly of $5 \mathrm{~cm}$, but no splenomegaly (figure). Standing height was $124.8 \mathrm{~cm}$, $4 \cdot 1 \mathrm{SD}$ below the mean for age. Body segments were disproportionate with sitting height $5.8 \mathrm{SD}$ and subischial leg length $3 \cdot 1$ SD below the mean for age. Height velocity over the previous three years was $1.1 \mathrm{~cm} /$ year and bone age was six years behind chronological age.

A low postexercise growth hormone estimation $(9.6 \mathrm{mU} / \mathrm{l})$ was followed up with a combined test of pituitary function. ${ }^{5}$ Plasma glucose, growth hormone (GH), cortisol, thyroid stimulating hormone (TSH), prolactin (PRL), luteinising hormone, $(\mathrm{LH})$, and follicle stimulating hormone ( $\mathrm{FSH})$ were measured serially after the concurrent administration of intravenous insulin $(0 \cdot 15 \mathrm{U} / \mathrm{kg})$, thyrotrophin releasing

TABLE Serial blood sugar, cortisol, and anterior pituitary hormones after intravenous insulin $0.15 \mathrm{U} / \mathrm{kg}, \mathrm{TRH} 200 \mu \mathrm{g}$, and $\mathrm{LHRH} 100 \mu \mathrm{g}$.

\begin{tabular}{|c|c|c|c|c|c|c|c|}
\hline $\begin{array}{l}\text { Time } \\
\text { (min) }\end{array}$ & $\begin{array}{l}\text { Blood sugar } \\
(\mathrm{mmol} / \mathrm{l})\end{array}$ & $\begin{array}{l}\text { Cortisol } \\
\text { (nmolll) }\end{array}$ & $\begin{array}{l}G H \\
(m U / l)\end{array}$ & $\begin{array}{l}T S H \\
\left(m U^{\prime \prime l}\right)\end{array}$ & $\begin{array}{l}P R L \\
(m U / l)\end{array}$ & $\begin{array}{l}L H \\
(U / l)\end{array}$ & $\begin{array}{l}F S H \\
(U / l)\end{array}$ \\
\hline 0 & $4 \cdot 4$ & 410 & 3.9 & 1.8 & 185 & $2 \cdot 3$ & 1.0 \\
\hline 20 & 1.2 & 430 & 8.5 & $7 \cdot 8$ & 660 & $12 \cdot 0$ & $2 \cdot 0$ \\
\hline 30 & $1 \cdot 1$ & 460 & 13.0 & - & - & - & - \\
\hline 45 & 2.9 & 600 & 35.0 & - & - & - & - \\
\hline 60 & 3.5 & 620 & 46.0 & $5 \cdot 6$ & 410 & $17 \cdot 0$ & $2 \cdot 8$ \\
\hline 90 & $3 \cdot 7$ & 460 & 55.0 & - & - & - & - \\
\hline 120 & $4 \cdot 1$ & 460 & $22 \cdot 0$ & - & - & - & - \\
\hline
\end{tabular}


hormone (TRH) $200 \mu \mathrm{g}$, and luteinising hormone releasing hormone (LHRH) $100 \mu \mathrm{g}$. The results shown in the table were all within normal limits indicating normal anterior pituitary function.

\section{Discussion}

Young and Harper ${ }^{1}$ discussed the cause of the consistent finding of short stature in MPS IIB. They considered that osseous growth plate disturbance may be partially responsible, since osteocytes and chondrocytes have been reported as showing storage abnormalities in the mucopolysaccharidoses. They also suggested that pituitary function might be impaired, since necropsy on one of their cases described by Millman and Whittick ${ }^{2}$ showed enlargement of the anterior lobe of the pituitary. These authors also reported arrest of ossification at the costochondral junctions with practically no proliferation of cartilage and little osteoblastic or osteoclastic activity. Periosteal thickening and infiltration by vacuolated cells were also noted. In the pituitary the most common cell was a degenerate one with finely vacuolated pale cytoplasm.

Necropsy on another probable case of MPS IIB $^{3}$ and eight cases of 'gargoylism'4 also showed pituitary abnormalities. The consistent finding was the presence of vacuolated cells that were considered as evidence of abnormal storage which might interfere with pituitary function.
Anterior pituitary function was normal in our patient, thus excluding growth hormone deficiency as a cause of his short stature. Thus, osseous growth plate disturbance with epiphyseal infiltration by mucopolysaccharides is the most likely cause of the short stature.

We thank Jean Mossman, Enzyme Laboratory, The Hospital for Sick Children, Great Ormond Street, London, for two dimensional electrophoresis of the urinary glycosaminoglycans and Derek Rees, Institute of Medical Genetics, University Hospital of Wales, Cardiff, for the iduronate sulphatase assay.

\section{References}

1 Young ID, Harper PS. Mild form of Hunter's syndrome: clinical delineation based on 31 cases. Arch Dis Child 1982;57:828-36.

2 Millman CG, Whittick JW. A sex-linked variant of gargoylism. J Neurol Neurosurg Psychiatry 1952;15:253-9.

${ }^{3}$ Smith EB, Hempelmann TC, Moore S, Barr DP. Gargoylism (dysostosis multiplex): two adult cases with one autopsy. Ann Intern Med 1952;36:652-67.

${ }^{4}$ Lindsay S, Reilly WA, Gotham TJ, Skahen R. Gargoylism II Study of pathologic lesions and clinical review of twelve cases. Am J Dis Child 1948;76:239-306.

5 Milner RDG, Burns EC. Investigation of suspected growth hormone deficiency. Arch Dis Child 1982;57:944-7.

Correspondence to Dr John Nelson, Staff Specialist Clinical Genetics, Westmead Hospital, Westmead, Sydney, NSW 2145, Australia. 